Société d'histoire de la révolution de 1848 et des

révolutions du XIXe siècle

$19 \mid 1999$

Aspects de la production culturelle au XIXe siècle

\title{
L'industrialisation de la production théâtrale : l'exemple de Scribe et de ses collaborateurs
}

Jean-Claude Yon

\section{OpenEdition}

Journals

Édition électronique

URL : http://journals.openedition.org/rh19/156

DOI : $10.4000 /$ rh 19.156

ISSN : $1777-5329$

Éditeur

La Société de 1848

Édition imprimée

Date de publication : 1 décembre 1999

Pagination : 77-88

ISSN : 1265-1354

Référence électronique

Jean-Claude Yon, «L'industrialisation de la production théâtrale : l'exemple de Scribe et de ses collaborateurs ", Revue d'histoire du XIXe siècle [En ligne], 19 | 1999, mis en ligne le 26 août 2008 consulté le 20 avril 2019. URL : http://journals.openedition.org/rh19/156 ; DOI : 10.4000/rh19.156

Ce document a été généré automatiquement le 20 avril 2019

Tous droits réservés 


\title{
L'industrialisation de la production théâtrale : l'exemple de Scribe et de ses collaborateurs
}

\author{
Jean-Claude Yon
}

\section{RÉSUMÉS}

La production théâtrale du XXe siècle se caractérise par son ampleur qui en fait une production de masse, à caractère industriel. Afin de produire à un rythme soutenu, les auteurs dramatiques ont recours à la collaboration. Le cas d'Eugène Scribe (1791-1861), dont le répertoire est riche de 425 ouvrages, permet d'étudier en détails ce phénomène qui, pour être dénoncé par la critique, n'en domine pas moins la production dramatique de tout le siècle.

Nineteenth century theatrical production is characterized by its copiousness which makes it a mass production on an industrial scale. In order to write a great number of plays, dramatists resort to collaboration. The case of Eugène Scribe (1791-1861), whose repertory contains 425 works, allows us to study in detail these phenomenon that, though exposed by critics, is none the less the prevailing feature of theatrical production all along the century.

\section{INDEX}

Mots-clés : Théâtre, Histoire culturelle 